\title{
PENERAPAN MODEL COOPERATIVE LEARNING METODE THINK PARE SHARE SEBAGAI UPAYA PENINGKATAN PRESTASI MATA KULIAH PENGANTAR BISNIS DI PROGRAM STUDI PENDIDIKAN EKONOMI TAHUN AKADEMIK 2019/2020
}

\author{
Ninik Srijani \\ Universitas PGRI Madiun \\ ninikikipae@gmail.com
}

\begin{abstract}
"The TPS (Think Pair Share) method is a learning process that stimulates students to think, discuss in pairs, and present or share opinions with other students". With this method students can attend lectures by thinking, collaborating, and sharing activities with fellow students who take the Introduction to Business course in the same semester. However, the reality is that there is learning in the classroom that it is difficult for lecturers to conduct classroom management, interaction between lecturers and students is less than optimal, this is because in general lecturers in giving lectures, teaching by explaining the material by relying on the lecture method, so students become passive and more is a "teacher center". It is hoped that by applying the TPS method in student learning it can find learning material independently by being guided by lecturers, then solving problems by thinking, then pairing up with discussion partners and then sharing, then learning in class will encourage students to be more active and create learning that is "student center "With the implementation of the School Assignment Assignment Program implemented in the Economic Education Study Program in the Introduction to Business course using the TPS (Think-Pair-Share) method of learning in student classrooms is more active and attentive to the material being taught. Implementation of the TPS method can run well as planned and has been implemented in the learning process
\end{abstract}

Keywords: Cooperative Learning Learning, TPS (Think-Pair-Share) method, Learning Achievement

\begin{abstract}
Abstrak
"Metode TPS (Think Pair Share) adalah proses pembelajaran yang merangsang mahasiswa untuk berfikir, mendiskusikan secara berpasangan, dan mempersentasikan atau berbagi pendapat dengan mahasiswa yang lain". Dengan metode ini mahasiswa dapat mengikuti perkuliahan dengan jalan berpikir, berkerjasama, dan melakukan kegiatan berbagi pada sesama mahasiswa yang menempuh mata kuliah Pengantar Bisnis pada semester yang bersamaan. Namun, kenyataannya yang ada pembelajaran di kelas yang terjadi dosen sulit melakukan pengelolaaan kelas, interaksi antara dosen dan mahasiswa kurang optimal, hal ini dikarenakan pada umumnya dosen dalam memberi kuliah, mengajar dengan menerangkan materi dengan bergantung pada metode ceramah, sehingga mahasiswa menjadi pasif dan lebih bersifat "teacher center". Harapannya dengan diterapkannya metode TPS dalam pembelajaran mahasiswa dapat menemukan materi pembelajaran secara mandiri dengan dipandu oleh dosen, kemudian memecahkan masalah dengan berpikir, kemudian berpasasangan dengan teman diskusi dan kemudian berbagi, maka pembelajaran di kelas akan mendorong mahasiswa lebih aktif dan tercipta pembelajaran yang "student center" Dengan pelaksanaan penerapan Program Penugasan dosen di Sekolah yang diterapkan di Program studi Pendidikan Ekonomi pada mata kuliah Pengantar Bisnis dengan menggunakan metode TPS (Think-Pair-Share) pembelajaran di kelas mahasiswa lebih aktif dan penuh perhatian terhadap materi yang diajarkan. Pelaksanaan metode TPS dapat berjalan dengan baik sesuai yang direncanakan dan sudah diimplementasikan dalam proses pembelajaran.
\end{abstract}

Kata Kunci: Pembelajaran Kooperatif Learning, metode TPS (Think-Pair-Share), Prestasi Belajar 


\section{PENDAHULUAN}

Pembelajaran di kelas selama ini masih menuntut dosen untuk memberi informasi secara searah dari Dosen ke mahasiswa yang hal ini berjalan terus menerus yang mengakibatkan muncul rasa jenuh baik pada diri mahasiswa juga pada diri dosen. Hal ini menyebabkan mahasiswa tidak muncul kemanidirian, rasa percaya diri, kurang kreative dan inovasi bahkan tidak ada kerjasama, saling memberi dan berbagi, berpikir bersama antar sesama mahasiswa. Oleh karena itu diterapkannya metode TPS ini bisa mengurangi rasa kejenuhan dan mahasiswa bisa aktif dalam pembelajaran di kelas. Penerapan ini diawali dengan membuat mahasiswa secara berpasangan untuk menemukan materi, kemudian mahasiswa memecahkan suatu permasalahan yang diberikan dosen. Salah satu metode yang diharapkan dapat meningkatkan prestasi belajar mahasiswa adalah metode TPS. Diharapkan dengan metode tersebut materi mata kuliah pengantar bisnis dapat dikaji lebih mendalam, lebih detail, yang harapannya mahasiswa lebih paham lebih menguasai materi dengan cara berpikir bersama, bekerja bersama, sehingga dapat bisa saling berbagi dan menerima materi dengan sesama mahasiswa. Untuk memperoleh prestasi belajar yang baik maka setiap mahasiswa harus lebih giat belajar. Metode TPS merangsang mahasiswa untuk selalu ingin tahu dan menemukan informasi, mengerti dan paham materi pengantar bisnis dan merasa puas apabila bisa berbagi kepada teman mahasiswa yang lain.

Metode TPS ini merupakan jenis pembelajaran kooperatif yang dirancang untuk mempengaruhi pola interaksi mahasiswa. Dan merupakan suatu cara yang efektif untuk membuat variasi suasana pola diskusi kelas". Dengan demikian penerapan metode TPS (Think-Pair-Share) sangat berpengaruh terhadap prestasi belajar mahasiswa, hanya dengan keuletan dan optimal diri yang dapat membantu untuk mencapainya. Metode TPS (Think-PairShare) dapat membantu mahasiswa agar memahami dan menguasai materi pelajaran. "TPS (Think Pair Share) adalah salah satu metode pengajaran yang dapat digunakan secara efektif untuk mengarahkan pembelajar dalam mempelajari sebuah materi dengan tema tertentu" "Model pembelajaran TPS (Think Pair Share) adalah salah satu model pembelajaran yang memberi kesempatan kepada setiap siswa untuk menunjukkan partisipasi kepada orang lain" "TPS (Think Pair Share) adalah suatu strategi diskusi kooperatif (kerjasama) yang memberikan kepada siswa waktu untuk berfikir dan merespon serta saling bantu satu sama lainnya" "Metode TPS (Think Pair Share) adalah proses pembelajaran yang merangsang siswa untuk berfikir, mendiskusikan secara berpasangan, dan mempersentasikan atau berbagi pendapat dengan siswa yang lain" dari uraian di atas maka program ini adalah salah satu penerapan program PDS di LPTK

\section{METODE PENELITIAN}

Dalam Penelitian Best Practice ini menggunakan penelitian analisis Kualitatif, dengan subyek penelitian semua mahasiswa semester I Tahun akademik 2019/2020 Program Studi Pendidikan Ekonomi, FKIP UNIPMA yang menempuh Mata Kuliah Pengantar Bisnis. Sedang data diambil dengan melakukan pengamatan secara langsung pada pembelajaran di kelas pada saat perkuliahan selama satu semester yaitu semester gasal 2019/2020.

\section{HASILDAN PEMBAHASAN}

Hasil yang diharapkan dari kegiatan best practice yang dilakukan dalam Program penugasan dosen ke sekolah adalah sebagai berikut: 1) Meningkatnya Kualitas Pembelajaran Di Kelas, 2) Meningkatnya Keaktifan, 
Kemampuan Dan Keberhasilan Siswa, 3) Meningkatnya Profesionalisme Dosen Dalam Melakukan Tri Dharma di Perguruan Tinggi. 4) Meningkatnya Prestasi Mahasiswa Dalam Mata Kuliah Pengantar Bisnis.

Pelaksanaan Dan Hasil Penyelesaian Masalah Pelaksanaan yang diterapkan untuk meningkatkan profesionalisme guru dalam pembelajaran siswa dan meningkatkan kualitas pembelajaran, meningkatkan prestasi belajar siswa, meningkatkan aktivitas belajar siswa baik secara individual maupun secara kelompok adalah sebagai berikut:

1. Berdasarkan hasil observasi terhadap pembelajaran di kelas masih rendahnya kreativitas, kerjasama, percaya diri mahasiswa dalam mengikuti perkuliahan mata kuliah pengantar bisnis.

2. Dalam memberi kuliah hendaknya dosen lebih kreatif, inovatif, merangsang mahsiswa lebih aktif dan percaya diri sehingga model pembelajaran yang dilakukan di kelas tidak hanya searah artinya sumber informasi tidak hanya satu satunya dari dosen tetapi juga dari mahasiswa itu sendiri, dan sesame mahasiswa yang lain. Dengan strategi dan model pembelajaran yang sesuai tentu masiswa akan lebih senang dan antusias untuk mengikuti perkuliahan. Salah satu model pembelajaran yang bisa digunakan adalah model pembelajaran kooperatif learning ini mempunyai manfaat untuk meningkatkan rasa tanggung jawab siswa terhadap pembelajarannya sendiri dan juga pembelajaran orang lain.

Pembelajaran yang dilaksanakan hendaknya disesuaikan dengan model pembelajaran kooperatif dan penggunaan Model TPS (Think-Pair-Share) Berikut ini adalah langkah-langkah pembelajaran kooperatif dengan Model TPS. Kegiatan awal : Dosen dalam pembelajaran memberi masalah-masalah yang dikaitkan dengan pelajaran, dan meminta masiswa menggunakan waktu beberapa menit untuk berpikir sendiri atas jawaban atau masalah. Kegiatan ke dua yaitu: Berpasangan, dosen meminta masiswa untuk berpasangan dan mendiskusikan apa yang telah mereka peroleh. Interaksi selama waktu yang disediakan dapat menyatukan jawaban jika suatu pertanyaan yang diajukan menyatukan gagasan masalah khusus yang diidentifikasi. Kegiatan ke tiga yaitu Berbagi, Dosen meminta pasanganpasangan untuk berbagi dengan keseluruhan kelas yang telah mereka bicarakan. Hal ini sangat efektif untuk berkeliling ruangan dari pasangan satu ke pasangan yang lain dan melanjutkan sampai sekitar sebagian pasangan mendapat kesempatan untuk melaporkan. Berdasarkan pelaksanaan Program PDS yang telah dilakukan di Siswa kelas X PBK SMK CENDEKIA Kota Madiun, guru mitra dan dosen pembelajaran yang telah dilakukan sudah terencana dan terlaksana dengan baik. Siswa kelas $\mathrm{X}$ PBK SMK CENDEKIA Kota Madiun sudah antusias dalam mengikuti pembelajaran. Siswa tidak jenuh dan senang dalam mengikuti pembelajaran. Dalam penggunaan model pembelajaran TPS, guru melakukan pembelajaran dengan melibatkan siswa dalam proses pembelajaran. Siswa diberi materi untuk dipikirkan bersama kemudian mendiskusikan dengan sesama teman kemudian membagikan ke teman yang lain, dari sini akan terlihat keaktifan siswa Dengan penggunaan media gambar siswa dapat memahami materi yang disampaikan oleh guru dan dapat mengambil kesimpulan dari materi yang telah diajarkan oleh guru. Namun dalam merencanakan langkah-langkah pembelajaran guru kurang menjelaskan secara spesifik mengenai gambar apa 
yang digunakan saat mengajar. Meskipun demikian, media gambar yang digunakan guru cukup bervariasi karena tidak hanya satu jenis akan tetapi meliputi media visual, media cetak, selain itu guru juga menggunakan media yang disediakan oleh sekolah serta media yang mudah diperoleh. Sebelum mengajar guru sudah merencanakan media pembelajaran yang akan digunakan untuk membantu dalam mengajar maupun dalam proses belajar mengajar. Kemudian pada tahun akademik 2019/2020 program PDS ini diterapkan pada perkuliahan Pengantar Bisnis pada semester 1 Program studi Pendidikan Ekonomi, FKIP UNIPMA, dengan harapan:

1. Mahasiswa dapat lebih mengetahui, memahami dan mengkaji secara lebih mendalam tentang materi perkuliahan.

2. Mahasiswa belajar berpikir secara bersama. Bekerjasama dalam menyelesaikan masalah, menghargai pendapat orang lain, saling memberi dan berbagi informasi dan materi perkuliahan kepada sesama mahasiswa.

3. Dalam pembelajaran dosen tidak melakukan pemberian informasi secara searah tetapi pembelajaran yang ada di kelas lebih menampakkan keaktifan mahasiswa, dosen dituntut untuk mengamati aktivitas mahasiswa, presentasi mahasiswa, dan mengarahkan jalannya diskusi dan presentasi mahasiswa.

\section{Kelebihan dan Kelemahan Pembelajaran Model TPS (Think-Pair-Share)}

a. Kelebihan model pembelajaran kooperatif tipe TPS (Think-pair-share) antara lain :

1) Memungkinkan siswa untuk merumuskan dan mengajukan pertanyaan mengenai materi yang diajarkan

2) Siswa akan terlatih menerapkan konsep

3) Siswa lebih aktif dalam pembelajaran

4) Siswa memperoleh kesempatan untuk mempersentasikan hasil diskusinya

5) Memungkinkan guru untuk lebih banyak memantau siswa dalam proses pembelajaran

b. Kelemahan model pembelajaran kooperatif tipe TPS (Think pair share) antara lain :

1) Sulit diterapkan di sekolah yang ratarata kemampuan siswanya rendah dan waktu yang terbatas

2) Banyak kelompok yang melapor dan perlu dimonitor

3) Lebih sedikit ide yang muncul

4) Tidak ada penengah jika terjadi perselisihan dalam kelompok (Arif Fadholi. 2009.Online)

\section{PENUTUP \\ Simpulan}

Simpulan berdasarkan permasalahan pada temuan best pactice bahwa penggunaan model pembelajaran kooperatif tipe TPS (Think pair share) sudah berjalan dengan baik. Pembelajaran sudah terencana dengan baik. Penggunaan model pembelajaran kooperatif tipe TPS (Think pair share) sudah diimplementasikan dalam proses pembelajaran. Dengan harapan dapat meningkatkan kualitas pembelajaran sehingga akan dapat meningkatkan prestasi belajar siswa.

\section{Saran}

Berdasarkan pada simpulan hasil penelitian diatas, penggunaan pembelajaran Model Kooperatif Tipe TPS (Think-PairShare) lebih efektif dalam membangkitkan keaktifan dan kreativitas belajar siswa. Untuk itu ada beberapa saran yang ingin penulis sampaikan, diantaranya: 
1. Bagi dosen

a. Dalam melaksanakan perkuliahan dosen hendaknya memberi kebebasan kepada mahasiswa untuk memilih pasangannya sendiri namun tetap dipandu oleh dosen pengampu, untuk meminimalisir keaktifan mahasiswa yang tidak proporsional.

b. Dosen Perlu memberikan motivasi, penanaman kerjasama dan kesempatan yang sama dalam melakukan presentasi diantara sesama mahasiswa.

c. Dalam perkuliahan dosen menyediakan waktu yang lebih intensif kepada mahasiswa untuk memandu jalannya presentasi dan diskusi.

d. Dosen dalam perkuliahan hendaknya menggunakan model pembelajaran yang bervariasi.

e. Dalam pemilihan model pembelajaran yang diterapkan di perkuliah dan hendaknya disesuaikan dengan karakeristik materi kuliah dan waktu yang tersedia.

f. Perlunya persiapan yang matang dari dosen untuk menguasai model pembelajaran yang akan diimplementasikan dalam pembelajaran.

2. Bagi mahasiswa

a. Untuk memotivasi agar mahasiswa yang lain lebih aktif dalam perkuliahan maka diperlukan rasa kebersamaan, rasa toleransi, saling asah asih, asuh rasa saling berbagi antar sesama mahasiswa sehingga tidak ada mahasiswa yang merasa lebih rendah kemampuannya disbanding dengan mahasiswa yang lain atau sebaliknya.

b. Mahasiswa dapat menghargai pendapat mahasiswa yang lain dengan cara bekerjasama, berpikir bersama, dan saling berbagi.

c. Dalam mengikuti perkuliahan hendaknya penuh semangat, aktif dan selalu mengedepankan rasa kebersamaan.

\section{DAFTAR PUSTAKA}

Angkowo, R., dan A. Kosasih. (2007). Optimalisasi Media Pembelajaran. Jakarta: PT Grasindo.

Aqib, Z. (2013). Model-Model, Media, dan Strategi Pembelajaran Kontekstual (Inovatif). Bandung: Yrama Widya.

Arsyad, A. (2011). Media Pembelajaran. Jakarta: Rajawali Pers.

Daryanto. (2010). Media Pembelajaran. Bandung: Satu Nusa.

Dirman dan Cicih Juarsih. (2014). Karakteristik Peserta Didik. Jakarta: PT Rineka Cipta.

Hajar, I. (2013). Panduan Lengkap Kurikulum Tematik. Jogjakarta: DIVA press.

Kurniawan, D. (2014). Pembelajaran Terpadu Tematik (Teori, Praktik, dan Penilaian). Bandung: Alfabeta.

Mertler, C. (2012). Action Research Mengembangkan Sekolah Memberdayakan Guru. Terjemahan oleh Daryatno. 2011. Yogyakarta: Pustaka Pelajar.

Moleong, L. (2012). Metodologi Penelitian Kualitatif. Bandung : PT Remaja Rosdakarya.

Munadi, Y. (2013). Media Pembelajaran Sebuah Pendekatan Baru. Jakarta: GP Press Group.

Rifai, M. (2015). Komunikasi Pendidikan. Madiun: Gama Grafika.

Sadiman, A. dkk. (2011). Media Pendidikan Pengertian, Pengembangan, dan Pemanfaatannya. Jakarta: Rajawali Pers.

Sanaky, AH Hujair. (2013). Media Pembelajaran Interaktif-Inovatif. Yogyakarta: Kaukaba Dipantara. 